\section{PREGNANT DOUBLE UTERUS}

\section{A. E. ACHER, M.D.}

FORT DODaE, IOWA

IIstory.-']he patient's fumily history was negative. She was 37 years old and had menstruated regularly every four Weeks, the menstrual period lasting about four days. She had hal six living children before present labor, and three misearriages. I curetted one of the patient's uteri about two years "go and did not discover anything unusual about her anatomy.

Present Pregnancy and Labor.-I was called on the morning of May 27, 1911, to sec patient. Pains were coming about acry fifteen minutes. Vaginal examinntion revealed dilatation to about the size of a dollar. At this time I noticed that the cervix was unusually high. Upon external examinution $I$ found two distinct tumors, one to the left and one to the right of the abdomen. 'The right was considerably higher than the left. On palpution I diseovered small parts and distinct motion on ench side. The dingnosis of twins was made. The (haracteristic thing about the abdomen was a decided crease between the two tumors. After making the usual examination I went away. On returning in the afternoon, I found strong pains eoming regularly, but dilatation progressing very slowly. So I went away again. Returning aguin at $9: 30 \mathrm{p}$. m. I found dilitation complete but nothing accomplished in the way of expulsion. The presenting head was as high as ever. The woman, beenuse of the long labor and unusually agonizing (hatracter of the puins, was becoming weak. Another plysician and nurse were called, patient put under complete anestliesia and after the usual preparation a high forceps delivery was performed of the presenting baby. When my right hand entered the vaginn to deliver the second child, I failed to find the baby in the dilated eervix, but the placenta was in evidence, which I delivered. But where was the second baby? Certainly not in the uterus from which the first came, because I latd just explored that. When my right hand entered the vagima again I foumd something I was not expecting, namely, by the side of the dilated ecrvix, another cervix which was only partly dilated. In the vagina this cervix was separnted from the first by a partition about one inch in thickness. I now discovered the real condition: two distinct and separnte Iteri, ench with a distinct cervix and a distinct body, and each containing a fully developed baby. I then proceeded to dilate the second cervix with my fingers, after which I delivered the second baby by high forceps. Both babies (girls, each weighing 5 pounds) are still living. The mother made an unerentful recovery.

\section{A CASE OF CEREBROSPINAL MENINGITIS}

\section{(. C. SNYDER, M.D., AND W. R. TYNDALE, M.J. SALT 1,AKE CITY}

Paticnt-April 20, 1911, the patient, a boy, aged 12, was tow ill to attend school and, with the exception of a few short intervals, remained in bed all day suffering from sick headache and pain in the leg. During the day lendnche was increased.

Course.-The next morning the mother gave him one-half cunce of maynesium sulphate, which was vomited almost immediately. Vomiting continued at intervals until midnight. Vomiting came on suddenly ench time, was projectile, and patient was unable to ruise his head. From 12 o'elock until 4 ॥. m., April 28, patient was comparatively quiet, when vomiting was resumed, and was incessunt until $11 \mathrm{a} . \mathrm{m}$. At 8 a. m. patient was given castor oil, which was jetained but a short time. The mother thonght the boy was suffering from typhoid fever, and applied sone mensures of her own. From il o'clock the vomiting was less severe lut during the night wлs renewed with previous severity and, when we saw him at 11 o'clock Friduy morning, April 29, for the first time he preseruted the following symptoms: unconscious, with heud and nock markedly retracted, and so rigid that hend could not be moved; face and lips cyanotic, pupils unequal, pulse rate about 80, very ir'egular unu very weak; tempernture, subnormal, 07 rectal; positive liernig; petechial hemorrhage, universal; Tnche cerebrale; hyperesthesia over the entire skin surfa:e; patellar and other reflexes increased; profound state of shock. Lıagnosis of epıcmic cerebrospinal meningıus was made.

Treatment.-Patient was removed to the Holy Cross Hospital and an ounce of cerebrospinal fluid was withdrawn and 30 c.c. of antimeningococcic serum (Mulford) was introduced into the spinal canal. The fluid withdrawn was somewhat viscid, cloudy and slightly tinged with blood. Microscopic examination showed large numbers of pus cells and of the Diplococeus intracellularis, both free and within the leukocytes. Twelve hours after serum had been injected patient regained consciousness and showed signs of improvement. On the three subsequent days 30 c.c. of serum were injected after the withdrawal of the same amount of cerebrospinal fluid. Patient's condition showed marked improvement during this period and after four days his condition was so much improved that further injections were thought unnecessary. Patient was given sodium bromid regularly for several days, as well as a lot bath daily. A course of calomel was given twice during patient's stay in the hospital.

On the seventl day patient complained of pain in his joints; pain was especially severe in the left knee joint. $A$ few doses of acetyl-salicylic acid controlled these symptoms. Patient remained in the hospital eighteen days, at which time he was apparently cured and is well at this time.

\section{Section Discussions}

\section{VACUUM FIXATION OF THE LENS AND FLAP SUTURE IN THE EXTRACTION OF THE CATARACT IN ITS CAPSULE}

\author{
VARD II, Jl[ILEN, A.M., M.D., HOUSTON, TEXAS
}

(Conclurled from page 189)

\section{Al3STRACT OF DISCUSSION}

Dr. G. C. Savage, Nashville: Dr. Hulen's operation appenled to me the moment I read about it. It is known to most of you that I devised an operation for the extraction of catarnct in its capsule and adopted a method that $I$ believe is more simple and efficient than the Smith operation. I would never have done it except that I knew that I would never do the Smith operntion. My metlod I liave before described. I believe that Dr. Hulen's methor is distinctly better than mine, and I am gladly willing to forget my own operation and Smith's for what Dr. Hulen has suggested. Do not let any one claim the operation. Let people tamper with the instrument as much as they want to, but do not let them tamper with the operation. I have had some experience in that line in regard to my muscle-shortening operation. Dr. Hulen's operation, I believe, will be the last to be devised for cataract extraction. All that we have to do is to let Dr. Hulen and others so perfect the instrument that he has devised and the exhaust-tube that he has nlso brought into use that none of us will be afraid to undertake it. Let us be a little careful while Dr. Hulen and others are making the perfected apparatus. I believe that J)r. Hulen is wrong in one step of his operation, and I told him so. I do not believe that the eye ought to be turned loose while that instrument is inside of it. 1 believe that the left hand-if the right eye is being operated on, and vice versa-should be set to the task of fixing that eye-ball so that it shall not move while the operation is being done, and that the very best method of flxing it is the grasp of the tendon of the internal rectus, which procedure 1 claimed, but laad to surrender to another. But with the eyc-ball fixed by means of the tendon-grasp, then with his instrument, mude lighter than it is now-it is too heavyand with that little cut-off entirely eliminated and some other means substituted, then introduce the instrument whether an iridectomy has been done or not, then let the exhaust be turned on, and I know that by shifting the instrument to 